\title{
BÍON, FR. IX
}

\author{
BION, FR. IX
}

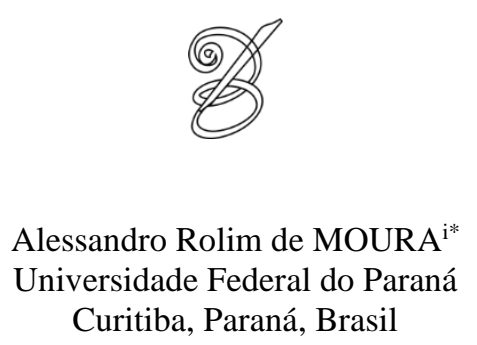

Resumo: Tradução de Bíon, fragmento IX.

Palavras-chave: Bíon. Poesia helenística. Poesia bucólica. Língua grega antiga. Tradução.

Abstract: Translation of Bion, fragment IX.

Keywords: Bion. Hellenistic poetry. Bucolic poetry. Ancient Greek language. Translation. 


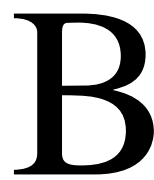

íon de Esmirna é considerado o terceiro dos bucólicos gregos (depois de Teócrito e Mosco). Escreveu por volta da passagem do século II para o I antes da Era Comum.

De acordo com o Epitáfio de Bíon, poema de um autor anônimo que se apresenta como epígono do homenageado, Bíon teria morrido prematuramente, vítima de envenenamento. Apresento aqui a tradução do fragmento IX do poeta de Esmirna, seguindo o texto de Gow.

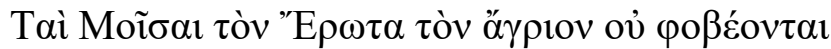

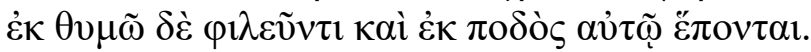

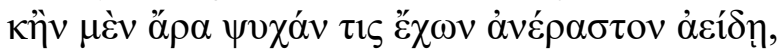

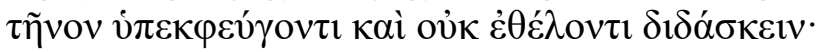

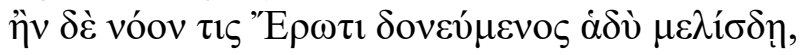

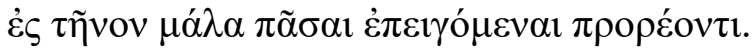

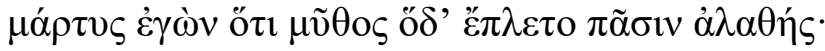

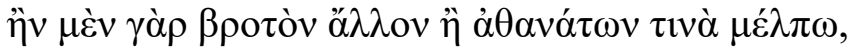

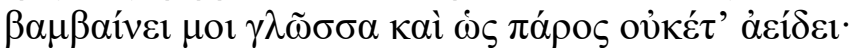

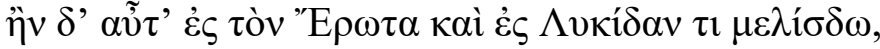

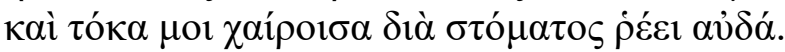

As Musas não têm medo do selvagem Eros, Mas de paixão o amam, seguem-no de perto. Portanto, se alguém canta sem amor na alma, Fogem dele e não querem nada lhe ensinar; A quem se agita em Eros e faz doce canto, Para ele apressadas correm todas elas. De que o dito é verdade pra todos atesto: Se eu canto qualquer um, homem ou um dos deuses, A língua já gagueja, não mais canta bem; Mas quando é para Eros ou para meu Lícidas, Da minha boca flui uma voz exultante.

\section{REFERÊNCIA}

GOW, A. S. F. Bucolici Graeci. Oxford: Oxford University Press, 1952.

\footnotetext{
i* Alessandro Rolim de MOURA - Graduado em Letras Português e Latim (1994) pela Universidade Federal do Paraná. Mestre em Letras - Letras Clássicas (2000) pela Universidade de São Paulo. Doutor em Letras Clássicas (2008) pela University of Oxford, Inglaterra. Realizou pesquisa pós-doutoral na University of London, Inglaterra (2017) e na Universidade Estadual de Campinas (2016-2018). Professor Associado de Literatura Grega e Latina. Universidade Federal do Paraná, Setor de Ciências Humanas, Departamento de Polonês, Alemão e Letras Clássicas. Curitiba, Paraná, Brasil.

Currículo acadêmico: http://lattes.cnpq.br/4938628531929137

ORCID: https://orcid.org/0000-0001-9933-8279

E-mail: alessandro.rolimdemoura@ufpr.br
} 